\title{
Synthesis and conductivity of substituted heteropoly acid with Dawson structure $\mathrm{H}_{7}\left[\mathrm{Ga}\left(\mathrm{H}_{2} \mathrm{O}\right) \mathrm{P}_{2} \mathrm{~W}_{17} \mathrm{O}_{61}\right] \cdot 18 \mathrm{H}_{2} \mathrm{O}$
}

\author{
QIAN XueYu ${ }^{1}$, HE ZhiQi ${ }^{1}$, WU Qing Yin ${ }^{1 *}$, TONG Xia ${ }^{1}$, YAN WenFu ${ }^{2} \&$ GONG Jian ${ }^{3}$ \\ ${ }^{1}$ Department of Chemistry, Zhejiang University, Hangzhou 310027, China; \\ ${ }^{2}$ State Key Laboratory of Inorganic Synthesis and Preparative Chemistry, Jilin University, Changchun 130012, China; \\ ${ }^{3}$ Key Laboratory of Polyoxometalate Science of the Ministry of Education, Northeast Normal University, Changchun 130024, China
}

Received October 28, 2010; accepted December 5, 2010

\begin{abstract}
A new solid high-proton conductor, $\mathrm{H}_{7}\left[\mathrm{Ga}\left(\mathrm{H}_{2} \mathrm{O}\right) \mathrm{P}_{2} \mathrm{~W}_{17} \mathrm{O}_{61}\right] \cdot 18 \mathrm{H}_{2} \mathrm{O}$, a substituted heteropoly acid with Dawson structure, has been synthesized by the degradation/ion-exchange/freezing method. The product was characterized by potentiometric titration, chemical analysis, IR, UV, XRD and TG-DTA. Complex impedance measurements show a high conductivity $\left(5.44 \times 10^{-3} \mathrm{~S} / \mathrm{cm}^{2}\right.$ $50^{\circ} \mathrm{C}$ ), with an activation energy for proton conduction of $36.04 \mathrm{~kJ} / \mathrm{mol}$. The mechanism of proton conduction is the Vehicle mechanism.
\end{abstract}

heteropoly acid, Dawson structure, synthesis, conductivity, conductive mechanism

Citation: Qian X Y, He Z Q, Wu Q Y, et al. Synthesis and conductivity of substituted heteropoly acid with Dawson structure $\mathrm{H}_{7}\left[\mathrm{Ga}_{2}\left(\mathrm{H}_{2} \mathrm{O}\right) \mathrm{P}_{2} \mathrm{~W}_{17} \mathrm{O}_{61}\right] \cdot 18 \mathrm{H}_{2} \mathrm{O}$. Chinese Sci Bull, 2011, 56: 2327-2330, doi: 10.1007/s11434-011-4445-8

Heteropoly acids (HPAs) have attracted increasing interest because of their applications, as catalysts for organic reactions, corrosion resistant coatings, dopants in sol-gel matrixes, and as membranes in selective electrodes, in gas detection apparatus, in solid-state electrochromic devices, and in liquid and solid electrolytic cells $[1,2]$. There are two kinds of protons in the HPA crystals. One is the dissociated, hydrated proton that is combined with the HPA anion, the other is the unhydrated proton that is located on the bridging oxygen in the HPA anion. Because the dissociated protons have good mobility, the HPA crystals have some characteristics of a 'pseudo liquid phase'. They are, in effect, superionic protonic conductors, and are promising solid electrolytes $[3,4]$. In recent years, studies on the conductivity of heteropoly acids have progressed rapidly, and the research fields have also been expanded from the initial binary heteropoly acid to ternary or quaternary heteropoly acids. However, the structure is still limited to the Keggin Structure, and there are few reports of heteropoly acids with other structures (such as the Dawson

*Corresponding author (email: qywu@zju.edu.cn) structure) [5-7]. This paper reports on the synthesis and characterization, as well as the proton conductivity, of a heteropoly acid with Dawson structure, $\mathrm{H}_{7}\left[\mathrm{Ga}\left(\mathrm{H}_{2} \mathrm{O}\right) \mathrm{P}_{2} \mathrm{~W}_{17} \mathrm{O}_{61}\right]$. $18 \mathrm{H}_{2} \mathrm{O}$. A possible mechanism of proton conduction for this heteropoly acid is proposed.

\section{Experimental}

\subsection{Instruments and reagents}

Nicolet Nexus 470 FT/IR spectrometer; SHIMADZU U-2550 UV-Vis spectrophotometer; BRUKER D8 ADVANCE X-ray diffractometer; SHIMADZU thermal analyzer and VMP2 Multichannel potentiostat electrochemical impedance analyzer (Princeton Applied Research).

All reagents were analysis grade.

\subsection{Preparation of HPA}

(1) Preparation of $\left[\mathrm{P}_{2} \mathrm{~W}_{17} \mathrm{O}_{61}\right]^{10-} . \quad\left[\mathrm{P}_{2} \mathrm{~W}_{18} \mathrm{O}_{62}\right]^{6-}\left(\mathrm{P}_{2} \mathrm{~W}_{18}\right)$ was prepared according to the literature $[8] .\left[\mathrm{P}_{2} \mathrm{~W}_{17} \mathrm{O}_{61}\right]^{10-}$ 
$\left(\mathrm{P}_{2} \mathrm{~W}_{17}\right)$ was prepared by a modification of this literature method. $\mathrm{P}_{2} \mathrm{~W}_{18}(20.0 \mathrm{~g})$ was dissolved in $50 \mathrm{~mL}$ of water, and $5 \mathrm{~g} \mathrm{KHCO}_{3}$ was dissolved in $50 \mathrm{~mL}$ of water. The latter solution was added dropwise to the former one with stirring. A white sediment appeared after stirring the mixed solution for an hour. $\mathrm{P}_{2} \mathrm{~W}_{17}$ was purified in $50 \mathrm{~mL}$ of water at $70^{\circ} \mathrm{C}$. Although $\mathrm{K}_{6} \mathrm{P}_{2} \mathrm{~W}_{18} \mathrm{O}_{62}$ was more soluble than $\mathrm{K}_{10} \mathrm{P}_{2} \mathrm{~W}_{17} \mathrm{O}_{61}$, it can still precipitate with $\mathrm{K}_{10} \mathrm{P}_{2} \mathrm{~W}_{17} \mathrm{O}_{61}$ when treated with potassium bicarbonate. In order to improve the purity of $\mathrm{K}_{10} \mathrm{P}_{2} \mathrm{~W}_{17} \mathrm{O}_{61}$, we used sodium bicarbonate instead of potassium bicarbonate.

(2) Preparation of $\mathrm{H}_{7}\left[\mathrm{Ga}\left(\mathrm{H}_{2} \mathrm{O}\right) \mathrm{P}_{2} \mathrm{~W}_{17} \mathrm{O}_{61}\right] \cdot 18 \mathrm{H}_{2} \mathrm{O}$. $\mathrm{H}_{7-}$ $\left[\mathrm{Ga}\left(\mathrm{H}_{2} \mathrm{O}\right) \mathrm{P}_{2} \mathrm{~W}_{17} \mathrm{O}_{61}\right] \cdot 18 \mathrm{H}_{2} \mathrm{O} \quad\left(\mathrm{P}_{2} \mathrm{~W}_{17} \mathrm{Ga}\right)$ can be prepared through initially degrading $\mathrm{P}_{2} \mathrm{~W}_{18}$ and then coordinating with $\mathrm{Ga}$ atoms using the vacancy formed in $\mathrm{P}_{2} \mathrm{~W}_{17}$ to form a $\mathrm{GaO}_{6}$ type octahedron.

$\mathrm{K}_{2} \mathrm{CO}_{3}(3 \mathrm{~g})$ was dissolved in $30 \mathrm{~mL}$ of water and this solution was added dropwise to $8.7 \mathrm{~mL} 0.6031 \mathrm{~mol} / \mathrm{L}$ $\mathrm{Ga}\left(\mathrm{NO}_{3}\right)_{3}$ solution. The prepared $\mathrm{P}_{2} \mathrm{~W}_{17}$ was added to $80 \mathrm{~mL}$ water at $70^{\circ} \mathrm{C}$, and the $\mathrm{Ga}\left(\mathrm{NO}_{3}\right)_{3}$ solution was added dropwise to this $\mathrm{P}_{2} \mathrm{~W}_{17}$ solution. The solution was then stirred for $1 \mathrm{~h}$ at above $95^{\circ} \mathrm{C}$, the $\mathrm{pH}$ was controlled at 5 with $\mathrm{HAc}$ during the reaction. Then the solution was filtered, cooled to room temperature, and the filtrate was put into an icebox. The crystals which separated from the solution were collected. The crystals were recrystallized three times from 30 $\mathrm{mL}$ boiling water to give the ion-exchanged material. The solution was filtered and the filtrate which contained $\mathrm{P}_{2} \mathrm{~W}_{17} \mathrm{Ga}$ was concentrated. After drying the concentrated solution in the desiccator, $\mathrm{H}_{7} \mathrm{P}_{2} \mathrm{~W}_{17} \mathrm{Ga}$ was obtained.

\subsection{Elemental analysis}

Phosphorus, tungsten and gallium were analyzed by ICP, the amount of water was analyzed by thermogravimetry. Found: $\mathrm{Ga}, 1.49 \%$; $\mathrm{P}, 1.31 \%$; W, 67.84\%; $\mathrm{H}_{2} \mathrm{O}, 7.57 \%$.

Calculated for $\mathrm{H}_{7}\left[\mathrm{Ga}\left(\mathrm{H}_{2} \mathrm{O}\right) \mathrm{P}_{2} \mathrm{~W}_{17} \mathrm{O}_{61}\right] \cdot 18 \mathrm{H}_{2} \mathrm{O}: \mathrm{Ga}, 1.52 \%$; $\mathrm{P}, 1.35 \% ; \mathrm{W}, 67.94 \% ; \mathrm{H}_{2} \mathrm{O}, 7.43 \%$.

\subsection{Measurement of conductivity}

$\mathrm{H}_{7} \mathrm{P}_{2} \mathrm{~W}_{17} \mathrm{Ga}$ was compressed to a disc under a pressure of 15 $\mathrm{MPa}$ at room temperature $\left(18^{\circ} \mathrm{C}\right)$. The diameter was $10 \mathrm{~mm}$ and the thickness was $3.50 \mathrm{~mm}$. Two copper sheets were attached to the faces of the disc. Copper slices and copper wires were used as electrodes and lines, respectively. The proton conductivity was measured using a cell: copper $\mid$ sample $\mid$ copper. The temperature was varied from 18 to $50^{\circ} \mathrm{C}$. The cell was open to atmosphere during this measurement.

\section{Results and discussion}

\subsection{Determination of basicity}

The number of hydrogens and states of ionization in the
HPA can be determined by potentiometric titration [9]. The potentiometric titration (Figure 1) shows that the 7 protons of $\mathrm{H}_{7}\left[\mathrm{Ga}\left(\mathrm{H}_{2} \mathrm{O}\right) \mathrm{P}_{2} \mathrm{~W}_{17} \mathrm{O}_{61}\right] \cdot 18 \mathrm{H}_{2} \mathrm{O}$ are equivalent and are ionized in the same step.

\subsection{IR spectra}

The IR spectrum of HPA shows the jump between 2 vibrational energy levels of the electronic ground state. The vibrations of the oxygen bond reflect the change of mechanical and electronic properties of the bond, and every change has its own characteristic frequency. Vibrations corresponding to the Dawson-type heteropoly acid appear at $700-1100 \mathrm{~cm}^{-1}$. The vibration frequencies fall in the sequence of $v_{\mathrm{as}}\left(\mathrm{P}-\mathrm{O}_{\mathrm{a}}\right)>v_{\mathrm{as}}\left(\mathrm{M}-\mathrm{O}_{\mathrm{d}}\right)>v_{\mathrm{as}}\left(\mathrm{M}-\mathrm{O}_{\mathrm{b}}-\mathrm{M}\right)>v_{\mathrm{as}}\left(\mathrm{M}-\mathrm{O}_{\mathrm{c}}-\mathrm{M}\right),(\mathrm{M}=$ $\mathrm{W}, \mathrm{Ga})$. The vibration frequencies of $\mathrm{M}-\mathrm{O}_{\mathrm{c}}-\mathrm{M}$ and $\mathrm{M}-\mathrm{O}_{\mathrm{d}}$ are red shifted, while that of $\mathrm{M}-\mathrm{O}_{\mathrm{b}}-\mathrm{M}$ is blue shifted, compared with the corresponding vibration frequency of the Keggin-type heteropoly acid [10].

Figure 2 shows the IR spectra of $\mathrm{P}_{2} \mathrm{~W}_{18}$ and $\mathrm{P}_{2} \mathrm{~W}_{17} \mathrm{Ga}$. The characteristic bands of the heteropolyanion at 700$1100 \mathrm{~cm}^{-1}$ were observed, which indicates that the Dawson structure of $\mathrm{P}_{2} \mathrm{~W}_{17} \mathrm{Ga}$ was maintained. The characteristic bands of $\mathrm{P}_{2} \mathrm{~W}_{17} \mathrm{Ga}$ appear at 1090, 964, 914 and $796 \mathrm{~cm}^{-1}$, which correspond to $v_{\text {as }}\left(\mathrm{P}-\mathrm{O}_{\mathrm{a}}\right), v_{\mathrm{as}}\left(\mathrm{M}-\mathrm{O}_{\mathrm{d}}\right), v_{\mathrm{as}}\left(\mathrm{M}-\mathrm{O}_{\mathrm{b}}-\mathrm{M}\right)$ and $v_{\mathrm{as}}\left(\mathrm{M}-\mathrm{O}_{\mathrm{c}}-\mathrm{M}\right)$ vibrations, respectively, and the corre-

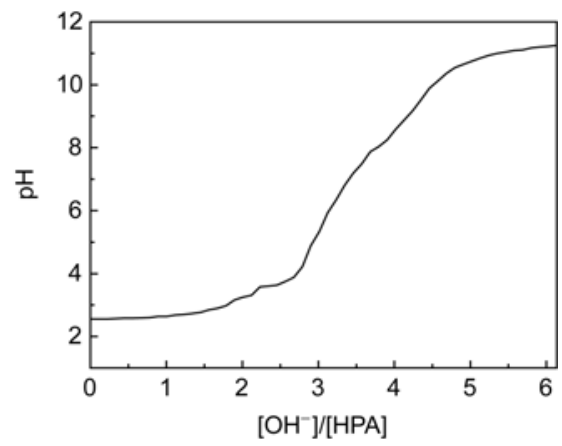

Figure 1 The potentiometric titration curve of $\mathrm{H}_{7}\left[\mathrm{Ga}\left(\mathrm{H}_{2} \mathrm{O}\right) \mathrm{P}_{2} \mathrm{~W}_{17} \mathrm{O}_{61}\right]$. $18 \mathrm{H}_{2} \mathrm{O}$.

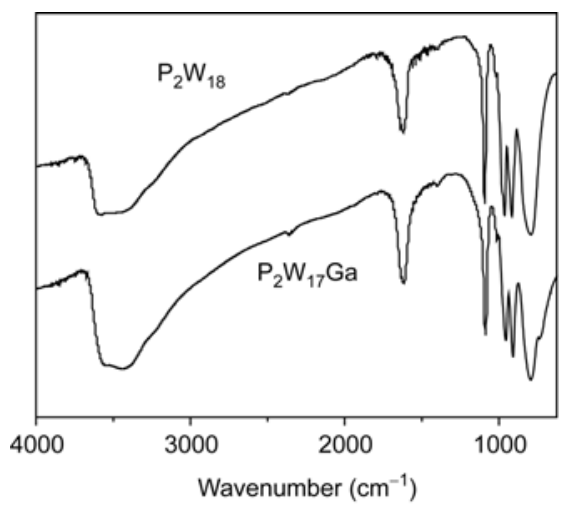

Figure 2 IR spectra of $\mathrm{P}_{2} \mathrm{~W}_{18}$ and $\mathrm{P}_{2} \mathrm{~W}_{17} \mathrm{Ga}$. 
sponding characteristic bands of $\mathrm{P}_{2} \mathrm{~W}_{18}$ appear at 1091.4, 963.4, 916.0 and $792.9 \mathrm{~cm}^{-1}$. The difference between the bands of the two compounds probably arises from the substitution of $\mathrm{Ga}$ atom. The bands at about 3450 and $1640 \mathrm{~cm}^{-1}$ were assigned to the stretching vibration of $\mathrm{O}-\mathrm{H}$ bonds and the bending vibration of $\mathrm{H}-\mathrm{O}-\mathrm{H}$ bonds, respectively.

\subsection{UV spectrum}

The absorptive band of the HPA UV spectrum shows the charge transfer between oxygen and a coordinate metal atom.

Figure 3 shows the UV spectrum of $\mathrm{H}_{7}\left[\mathrm{Ga}\left(\mathrm{H}_{2} \mathrm{O}\right) \mathrm{P}_{2^{-}}\right.$ $\left.\mathrm{W}_{17} \mathrm{O}_{61}\right] \cdot 18 \mathrm{H}_{2} \mathrm{O}$, there is an intense absorption peak at $197.5 \mathrm{~nm}\left(\mathrm{O}_{\mathrm{d}} \rightarrow \mathrm{W}\right)$ and a relatively weak absorption peak at $255 \mathrm{~nm}\left(\mathrm{O}_{\mathrm{b}} / \mathrm{O}_{\mathrm{c}} \rightarrow \mathrm{W}\right)$.

\subsection{X-ray powder diffraction}

$\mathrm{X}$-ray powder diffraction is widely used to study the structural features of HPA and explain their properties. Figure 4 shows the X-ray diffraction pattern of Dawson-type heteropoly acid $\mathrm{H}_{7}\left[\mathrm{Ga}\left(\mathrm{H}_{2} \mathrm{O}\right) \mathrm{P}_{2} \mathrm{~W}_{17} \mathrm{O}_{61}\right] \cdot 18 \mathrm{H}_{2} \mathrm{O}$. The most intense peaks exist at about $8.5^{\circ}$. In 4 ranges of $2 \theta$ (i.e. $7-10^{\circ}, 17-20^{\circ}$, $23-28^{\circ}$ and $28-30^{\circ}$ ), there are characteristic peaks of HPA anions with Dawson structure [11]. Combined with the IR and UV spectra, this confirms that $\mathrm{H}_{7}\left[\mathrm{Ga}\left(\mathrm{H}_{2} \mathrm{O}\right) \mathrm{P}_{2} \mathrm{~W}_{17} \mathrm{O}_{61}\right]$.

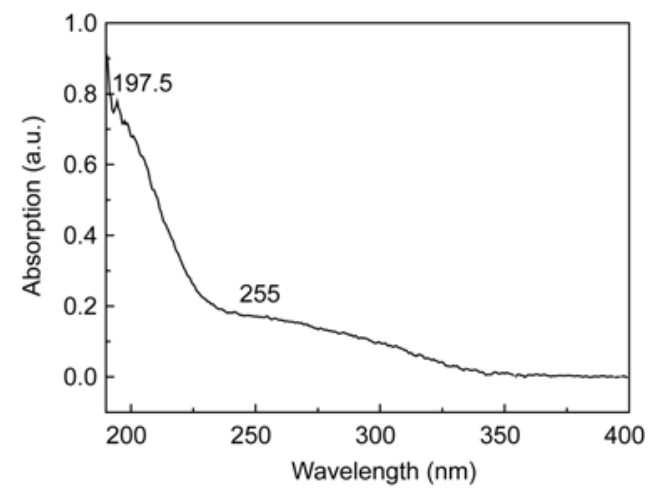

Figure 3 UV spectrum of $\mathrm{H}_{7}\left[\mathrm{Ga}\left(\mathrm{H}_{2} \mathrm{O}\right) \mathrm{P}_{2} \mathrm{~W}_{17} \mathrm{O}_{61}\right] \cdot 18 \mathrm{H}_{2} \mathrm{O}$.

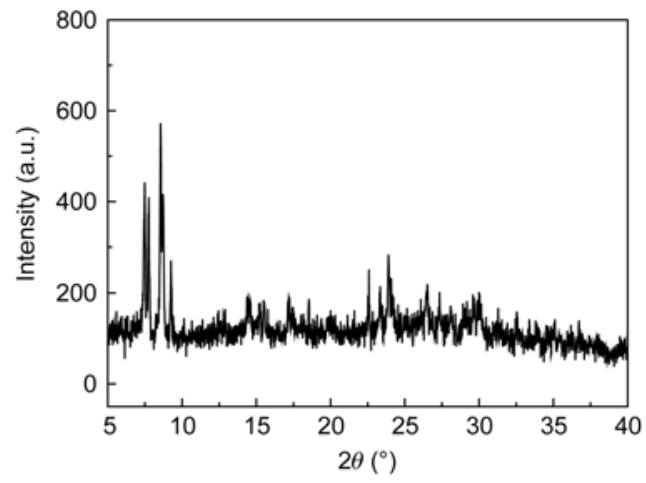

Figure 4 X-ray diffraction pattern of $\mathrm{H}_{7}\left[\mathrm{Ga}\left(\mathrm{H}_{2} \mathrm{O}\right) \mathrm{P}_{2} \mathrm{~W}_{17} \mathrm{O}_{61}\right] \cdot 18 \mathrm{H}_{2} \mathrm{O}$.
$18 \mathrm{H}_{2} \mathrm{O}$ has a Dawson structure.

Figure 5 shows a schematic diagram of the structure of the Dawson-type heteropoly acid $\mathrm{H}_{7}\left[\mathrm{Ga}\left(\mathrm{H}_{2} \mathrm{O}\right) \mathrm{P}_{2} \mathrm{~W}_{17} \mathrm{O}_{61}\right]$. $18 \mathrm{H}_{2} \mathrm{O}$.

\subsection{TG-DTA analysis}

HPA consists of protons, HPA anions and water. TG and DTA curves of $\mathrm{H}_{7}\left[\mathrm{Ga}\left(\mathrm{H}_{2} \mathrm{O}\right) \mathrm{P}_{2} \mathrm{~W}_{17} \mathrm{O}_{61}\right] \cdot 18 \mathrm{H}_{2} \mathrm{O}$ are shown in Figure 6. The TG curve shows that the total percent of weight loss is $7.57 \%$, which indicates that each HPA molecule has 19.26 water molecules. The TG curve shows that there are 3 steps of mass loss. The first is the loss of hydration water, the second is the loss of protonized water and the third is the loss of structural water. There is an $\mathrm{O}$ atom of a water molecule which is coordinated with the Ga atom and hence is directly connected to that Ga atom. Thus, the accurate molecular formula of the product is $\left(\mathrm{H}_{5} \mathrm{O}_{2}{ }^{+}\right)_{2} \mathrm{H}_{5^{-}}$ $\left[\mathrm{Ga}\left(\mathrm{H}_{2} \mathrm{O}\right) \mathrm{P}_{2} \mathrm{~W}_{17} \mathrm{O}_{61}\right] \cdot 14 \mathrm{H}_{2} \mathrm{O}$.

In general, we take the temperature of the exothermic peak of DTA curves of compounds as a way of characterizing their thermostability [12]. Figure 6 is the thermogram of $\mathrm{H}_{7}\left[\mathrm{Ga}\left(\mathrm{H}_{2} \mathrm{O}\right) \mathrm{P}_{2} \mathrm{~W}_{17} \mathrm{O}_{61}\right] \cdot 18 \mathrm{H}_{2} \mathrm{O}$. In the DTA curve, there are both endothermic and exothermic peaks. The process of dehydration occurring at $119.2^{\circ} \mathrm{C}$ is an endothermic peak.

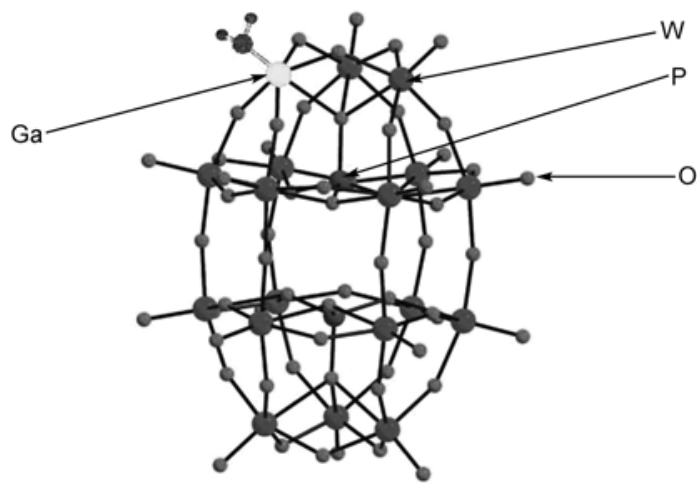

Figure 5 Schematic diagram of the structure of $\mathrm{H}_{7}\left[\mathrm{Ga}\left(\mathrm{H}_{2} \mathrm{O}\right) \mathrm{P}_{2} \mathrm{~W}_{17^{-}}\right.$ $\left.\mathrm{O}_{61}\right] \cdot 18 \mathrm{H}_{2} \mathrm{O}$.

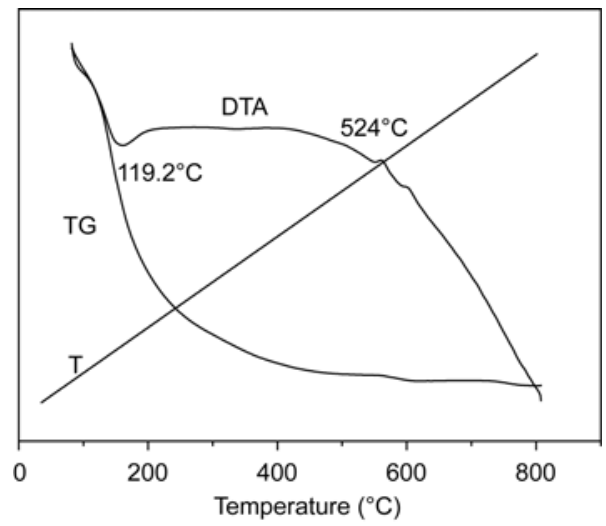

Figure 6 TG-DTA curve of $\mathrm{H}_{7}\left[\mathrm{Ga}\left(\mathrm{H}_{2} \mathrm{O}\right) \mathrm{P}_{2} \mathrm{~W}_{17} \mathrm{O}_{61}\right] \cdot 18 \mathrm{H}_{2} \mathrm{O}$. 
The exothermic peak at $524^{\circ} \mathrm{C}$ is due to the decomposition of Dawson-type heteropoly acid $\mathrm{H}_{7}\left[\mathrm{Ga}\left(\mathrm{H}_{2} \mathrm{O}\right) \mathrm{P}_{2} \mathrm{~W}_{17} \mathrm{O}_{61}\right]$. $18 \mathrm{H}_{2} \mathrm{O}$.

\subsection{Conductivity}

Conductivity is an important parameter. We have recorded the complex impedance spectra of the HPA (over a frequency range from $0.01 \times 10^{4}-9.99 \times 10^{4} \mathrm{~Hz}$ ). We can calculate the conductivity from these results as $\sigma=h /(S R)$, where $R$ is the resistance, $h$ is the thickness, and $S$ is the area of the tablet. The calculation shows that at $18,30,41$ and $50^{\circ} \mathrm{C}$, the conductivity values of $\mathrm{H}_{7}\left[\mathrm{Ga}\left(\mathrm{H}_{2} \mathrm{O}\right) \mathrm{P}_{2} \mathrm{~W}_{17} \mathrm{O}_{61}\right] \cdot 18 \mathrm{H}_{2} \mathrm{O}$ are $1.25 \times 10^{-3}, 2.52 \times 10^{-3}, 4.56 \times 10^{-3}$ and $5.44 \times 10^{-3} \mathrm{~S} / \mathrm{cm}$, respectively. This compound is a new solid high-proton conducting HPA.

The conductivity is a function of the movement of protons. There are two predominant mechanisms for proton conduction: the Vehicle mechanism and the Grotthuss mechanism [13]. In the Vehicle mechanism, water assists proton movement by facilitating transport as an $\mathrm{H}_{3} \mathrm{O}^{+}$species. This differs from the Grotthuss mechanism, in which a large amount of water can assist proton transport through a hydrogen-bonded network [14]. Kreuer [15] has suggested that the HPA acts as a Bronsted acid towards the hydration water, which is generally loosely bound in the structure, resulting in a high proton conductivity. Consequently, the conductivity of HPAs is strictly related to the numbers of water molecules coordinated to the Dawson unit. Generally, the activation energy of the Vehicle mechanism is higher $(20 \mathrm{~kJ} / \mathrm{mol}$ or more) than that of the Grotthuss mechanism $(10 \mathrm{~kJ} / \mathrm{mol}$ or less).

Figure 7 is an Arrhenius plot. From the slope we can calculate the activation energy of proton conduction is $36.04 \mathrm{~kJ} / \mathrm{mol}$, which indicates that its mechanism of proton conduction is the Vehicle mechanism. In the range of 18 to $50^{\circ} \mathrm{C}$, the conductivity of $\mathrm{H}_{7}\left[\mathrm{Ga}\left(\mathrm{H}_{2} \mathrm{O}\right) \mathrm{P}_{2} \mathrm{~W}_{17} \mathrm{O}_{61}\right] \cdot 18 \mathrm{H}_{2} \mathrm{O}$ increases with increasing temperature.

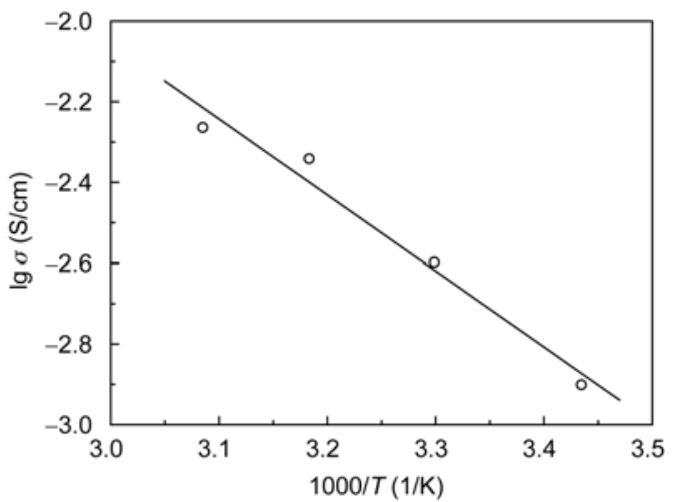

Figure 7 Arrhenius plot of $\mathrm{H}_{7}\left[\mathrm{Ga}\left(\mathrm{H}_{2} \mathrm{O}\right) \mathrm{P}_{2} \mathrm{~W}_{17} \mathrm{O}_{61}\right] \cdot 18 \mathrm{H}_{2} \mathrm{O}$.

\section{Conclusion}

$\mathrm{H}_{7}\left[\mathrm{Ga}\left(\mathrm{H}_{2} \mathrm{O}\right) \mathrm{P}_{2} \mathrm{~W}_{17} \mathrm{O}_{61}\right] \cdot 18 \mathrm{H}_{2} \mathrm{O}$, a new solid high-proton conducting HPA, was prepared and characterized for the first time. We determined the conductivity values of $\mathrm{H}_{7}\left[\mathrm{Ga}\left(\mathrm{H}_{2} \mathrm{O}\right) \mathrm{P}_{2} \mathrm{~W}_{17} \mathrm{O}_{61}\right] \cdot 18 \mathrm{H}_{2} \mathrm{O}$ using complex impedance measurements. They are $1.25 \times 10^{-3}, 2.52 \times 10^{-3}, 4.56 \times 10^{-3}$ and $5.44 \times 10^{-3} \mathrm{~S} / \mathrm{cm}$ at $18,30,41$ and $50^{\circ} \mathrm{C}$, respectively. The conductivity of $\mathrm{H}_{7}\left[\mathrm{Ga}\left(\mathrm{H}_{2} \mathrm{O}\right) \mathrm{P}_{2} \mathrm{~W}_{17} \mathrm{O}_{61}\right] \cdot 18 \mathrm{H}_{2} \mathrm{O}$ increases with temperature from 18 to $50^{\circ} \mathrm{C}$. The activation energy of proton conduction of $\mathrm{H}_{7}\left[\mathrm{Ga}\left(\mathrm{H}_{2} \mathrm{O}\right) \mathrm{P}_{2} \mathrm{~W}_{17} \mathrm{O}_{61}\right]$. $18 \mathrm{H}_{2} \mathrm{O}$ is $36.04 \mathrm{~kJ} / \mathrm{mol}$, indicating that its mechanism of proton conduction is the Vehicle mechanism.

This work was supported by the National Natural Science Foundation of China (21071124), the Natural Science Foundation of Zhejiang Province (Y4090183), the Foundation of State Key Laboratory of Inorganic Synthesis and Preparative Chemistry of Jilin University (2010-16) and the Foundation of Key Lab of Polyoxometalates Science of the Ministry of Education of Northeast Normal University (DS-20080102).

1 Nakamura O, Kodama T, Oginio I, et al. High-conductivity solid proton conductors-dodecamolybdophosphoric acid and dodecatungstophosphoric acid crystals. Chem Lett, 1979, 17-18

2 Coronado E, Gomez-Garcia C J. Polyoxometalate-based molecular materials. Chem Rev, 1998, 98: 273-296

3 Kim W B, Voitl T, Rodriguez-Rivera G J, et al. Powering fuel cells with $\mathrm{CO}$ via aqueous polyoxometalates and gold catalysts. Science, 2004, 305: 1280-1283

4 Wang X L, Zhang H, Wang E B, et al. Phosphomolybdate-polypyrrole composite bulk-modified carbon paste electrode for a hydrogen peroxide amperometric sensor. Mater Lett, 2004, 58: 1661-1664

5 Wu Q Y, Sang X G, Liu B, et al. Synthesis and performance of high-proton conductor undecatungstochromoindic heteropoly acid. Mater Lett, 2005, 59: 123-126

6 Wu Q Y, Sang X G, Shao F, et al. Synthesis and conductivity of undecatungstocobaltoindic heteropoly acid. Mater Chem Phys, 2005, 92: 16-20

7 Wu Q Y, Sang X G. Synthesis and conductivity of solid high-proton conductor $\mathrm{H}_{5} \mathrm{GeW}_{10} \mathrm{MoVO}_{40} \cdot 21 \mathrm{H}_{2} \mathrm{O}$. Mater Res Bull, 2005, 40: 405-410

8 Contant R. Potassium octadecatungstodiphosphates(V) and related lacunary compounds. Inorg Synth, 1990, 27: 104-111

9 Wu Q Y, Sang X G, Liu B, et al. Synthesis and performance of highproton conductor undecatungstochromoindic heteropoly acid. Mater Lett, 2005, 59: 123-126

10 Wu Q Y, Liu Y Q, Tang Y. Modern Inorganic Synthesis and Preparative Chemistry. Beijing: Chemical Industry Press, 2010

11 Wang E B, Hu C W, Xu L. Introduction for Polyoxometalates Chemistry. Beijing: Chemical Industry Press, 1998

12 Zhao S L, Wu Q Y, Huan X L, et al. Preparation and conductivity of substituted germanic heteropoly acids polyethylene glycol hybrid materials. J Appl Polym Sci, 2008, 107: 2545-2548

13 Checkiewicz K, Zukowaska G, Wieczorek W. Synthesis and characterization of the proton-conducting gels based on PVdF and PMMA matrixes doped with heteropolyacids. Chem Mater, 2001, 13: 379384

14 Janik M J, Davis R J, Neurock M. Anhydrous and water-assisted proton mobility in phosphotungstic acid. J Am Chem Soc, 2005, 127: 5238-5245

15 Kreuer K D. Proton conductivity: Materials and applications. Chem Mater, 1996, 8: 610-641

Open Access This article is distributed under the terms of the Creative Commons Attribution License which permits any use, distribution, and reproduction in any medium, provided the original author(s) and source are credited. 